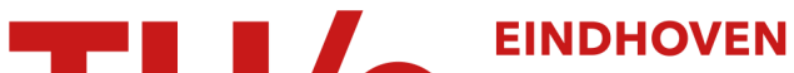 \\ UNIVERSITY OF \\ TECHNOLOGY
}

\section{Insight into clogging of micromachined cryogenic coolers}

\section{Citation for published version (APA):}

Lerou, P. P. P. M., Brake, ter, H. J. M., Holland, H. J., Burger, J. F., \& Rogalla, H. (2007). Insight into clogging of micromachined cryogenic coolers. Applied Physics Letters, 90(6), 064102-1/3. [064102].

https://doi.org/10.1063/1.2472194

DOI:

10.1063/1.2472194

Document status and date:

Published: 01/01/2007

\section{Document Version:}

Publisher's PDF, also known as Version of Record (includes final page, issue and volume numbers)

\section{Please check the document version of this publication:}

- A submitted manuscript is the version of the article upon submission and before peer-review. There can be important differences between the submitted version and the official published version of record. People interested in the research are advised to contact the author for the final version of the publication, or visit the $\mathrm{DOI}$ to the publisher's website.

- The final author version and the galley proof are versions of the publication after peer review.

- The final published version features the final layout of the paper including the volume, issue and page numbers.

Link to publication

\section{General rights}

Copyright and moral rights for the publications made accessible in the public portal are retained by the authors and/or other copyright owners and it is a condition of accessing publications that users recognise and abide by the legal requirements associated with these rights.

- Users may download and print one copy of any publication from the public portal for the purpose of private study or research.

- You may not further distribute the material or use it for any profit-making activity or commercial gain

- You may freely distribute the URL identifying the publication in the public portal.

If the publication is distributed under the terms of Article 25fa of the Dutch Copyright Act, indicated by the "Taverne" license above, please follow below link for the End User Agreement:

www.tue.nl/taverne

Take down policy

If you believe that this document breaches copyright please contact us at:

openaccess@tue.nl

providing details and we will investigate your claim. 


\title{
Insight into clogging of micromachined cryogenic coolers
}

\author{
P. P. P. M. Lerou, ${ }^{a)}$ H. J. M. ter Brake, ${ }^{b)}$ H. J. Holland, J. F. Burger, and H. Rogalla \\ Low Temperature Division, Faculty of Science and Technology, University of Twente, P.O. Box 217, \\ 7500 AE Enschede, The Netherlands
}

(Received 21 November 2006; accepted 10 January 2007; published online 7 February 2007)

\begin{abstract}
Cryogenic microcoolers can be used to cool small electronic devices to improve their performance. The authors present a micro-cold-stage of only $0.05 \mathrm{~cm}^{3}$ that cools to $96 \mathrm{~K}$, applying Joule-Thomson expansion in a $300 \mathrm{~nm}$ high flow restriction. Critical in such a microcooler is the deposition of water molecules that migrate to the restriction and block the flow. Because the microcooler is made of glass the authors had the unique opportunity to monitor this phenomenon and combine this visualization with experimental data. This provides significant insight in the way this clogging develops and opens possibilities to realize stable operation. (c) 2007 American Institute of Physics. [DOI: 10.1063/1.2472194]
\end{abstract}

The performance of electronic devices can often be improved by lowering the operating temperature, resulting in lower noise and larger speed. ${ }^{1}$ Also, specific phenomena can be applied at low temperatures, for instance, superconductivity. ${ }^{2}$ Although these electronic devices are very small $\left(\ll 1 \mathrm{~cm}^{3}\right)$, correspondingly small cryogenic coolers are not yet available. A major hurdle in developing microcoolers is clogging of the small channels because of moisture. In our microcooler project we had the unique opportunity to visualize this clogging mechanism. In this letter, we describe this mechanism and give a strategy to prevent clogging and to secure the operation of a micro-cold-stage.

The experiments were performed on a micro-cold-stage that can cool down to $100 \mathrm{~K}$ with a cooling power of $10 \mathrm{~mW}$ and measures only $30 \times 2 \times 0.5 \mathrm{~mm}^{3}\left(\approx 0.05 \mathrm{~cm}^{3}\right){ }^{3}$ Cooling is obtained by expanding nitrogen over a flow restriction that is $300 \mathrm{~nm}$ high. In contrast to earlier micro-cold-stages, ${ }^{4,5}$ this cold tip is optimized for maximum performance in combination with minimal size. ${ }^{6}$ Also, the production is fully based on microelectro mechanical system (MEMS) technology which makes it suitable for mass production, integration with integrated circuit technology based circuitry, and microvacuum packaging. ${ }^{7-9}$ The microcooler is based on a JouleThomson cycle in which nitrogen expands over a flow restriction from 80 to 6 bars. The temperature of the cold tip, $96 \mathrm{~K}$, is determined by the boiling temperature of nitrogen at 6 bars. The high and low pressures determine the available difference in specific enthalpy of the gas $(d h)$. The cooling power $\left(P_{\text {cool }}\right)$ is determined by the mass flow $(\dot{m})$ : $P_{\text {cool }}=\dot{m} d h$. This flow is chosen at $1 \mathrm{mg} \mathrm{s}^{-1}$ which results in a gross cooling power of about $15 \mathrm{~mW}$. In order to reduce parasitic heat loads to below this level, the cooler has to be operated in a vacuum environment. At the given pressures, the flow rate is determined by the restriction, in our case a very shallow channel of only $300 \mathrm{~nm}$ high. Further clarification of the cycle and the chosen parameters can be found in Ref. 6.

The cold stage consists of a stack of three glass wafers. ${ }^{3}$ In the top wafer, the high-pressure line is etched as a rectan-

\footnotetext{
${ }^{a)}$ Electronic mail: p.p.p.m.lerou@utwente.nl

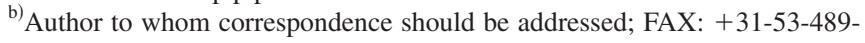

1099; electronic mail: h.j.m.terbrake@utwente.nl
}

gular channel with supporting pillars. This line ends in a flow restriction and an evaporator volume that crosses the center wafer into the bottom wafer. This bottom wafer contains the low-pressure line, again etched as a rectangular channel containing supporting pillars, thus forming a counterflow heat exchanger (CFHX). A critical issue in the operation of this cooler is clogging caused by the deposition of water molecules. By utilizing the fact that the cooler is built out of glass wafers we had the opportunity to monitor and visualize this clogging phenomenon.

In the measurement setup, high-purity nitrogen gas 6.0 is supplied from a gas bottle and led through a getter stabilized zeolite filter. According to its specifications, the outlet contamination should be below 1 ppb (parts per billion). Therefore, the contamination in the cooler is determined by the amount present at start-up. To minimize this initial contamination in the system, the setup is cleaned by pumping and heating. Through calculation, ${ }^{10}$ the initial pressure inside the cold stage was estimated at about $1 \mathrm{~Pa}$. In our experiments, the temperature at which the restriction starts to clog appeared to lie around $200 \mathrm{~K}$. From the relevant fluids, water is the only one that has a phase transition around that temperature at about $1 \mathrm{~Pa}$. The left graph of Fig. 1 shows the phase diagram of water. It can be seen that water changes its phase in the deposition from vapor to solid at about $200 \mathrm{~K}$ and $1 \mathrm{~Pa}$.

A typical cooldown registration is depicted in Fig. 2. The experimental mass-flow curve corresponds to theory (i.e., restriction height of $300 \mathrm{~nm}$ ) for temperatures above $200 \mathrm{~K}$. At around that temperature $\left(p_{\text {partial, } \mathrm{H}_{2} \mathrm{O}}=1 \mathrm{~Pa} \approx 0.1 \mathrm{ppm}\right)$, the mass-flow curve shows a small decrease of the slope. This is an indication that the restriction is getting partly clogged (point A). A layer of a few nanometers on the surface of the restriction already accounts for the measured effect. It results in a decrease of the mass flow and thus of cooling power. Nevertheless, the cooldown continues and below about $120 \mathrm{~K}$, the mass flow starts to fluctuate (point B). This massflow fluctuation indicates that liquid is being formed inside the evaporator. It also means that there is a relatively large temperature gradient from the evaporator to the flow restriction since at 6 bars nitrogen boils at $96 \mathrm{~K}$. The liquid nitrogen in the evaporator further cools the restriction, thus affecting the flow as depicted in Fig. 2. In the top graph of this figure, it can be seen that the measured temperature does not 

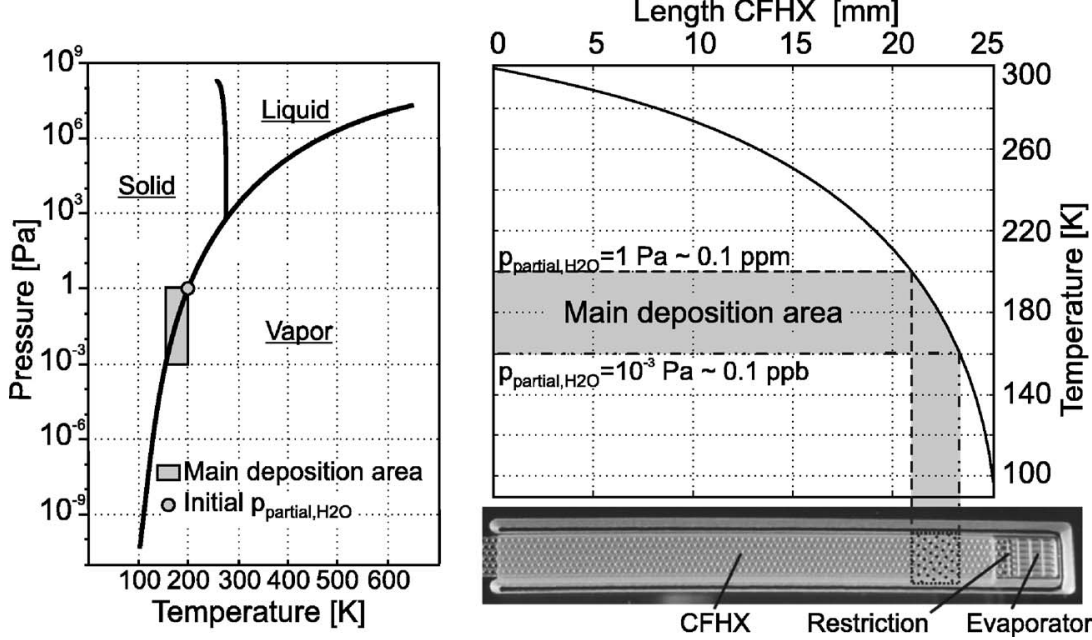

FIG. 1. Left: phase diagram of water. Data above $200 \mathrm{~K}$ are taken from Ref. 13. Data below $200 \mathrm{~K}$ are calculated using the Clausius-Clapeyron equation. Right: calculated temperature profile of the CFHX (Ref. 6) and a schematic representation of the main deposition area. Right bottom: photograph of a cold stage. reach the predicted $96 \mathrm{~K}$ but is about $110 \mathrm{~K}$. This temperature is measured with a thermocouple connected to the outside of the evaporator. The temperature difference of $14 \mathrm{~K}$ is caused by the thermal resistance formed by the thin layer of glass and the connection between the thermocouple and the cold stage.

From point $\mathrm{C}$, the cold tip stays in a semistable situation with constant flow and temperature. In this phase, there is a constant temperature gradient over the CFHX from about $100 \mathrm{~K}$ at the cold tip to $300 \mathrm{~K}$ at the warm end, see right plot in Fig. 1. The coldest part of the CFHX with a temperature below $200 \mathrm{~K}$ now acts as a water filter. Here, water molecules deposit on the CFHX wall and because of the relative large CFHX volume (the flow channel is $50 \mu \mathrm{m}$ high and $2 \mathrm{~mm}$ wide), this does not affect the mass flow. The partial pressure of water inside the nitrogen gas is reduced from $1 \mathrm{~Pa}$ at $200 \mathrm{~K}$ to about $10^{-10} \mathrm{~Pa}$ at $100 \mathrm{~K}$ which corresponds to a contamination of only about $10^{-11} \mathrm{ppm}$, in other words
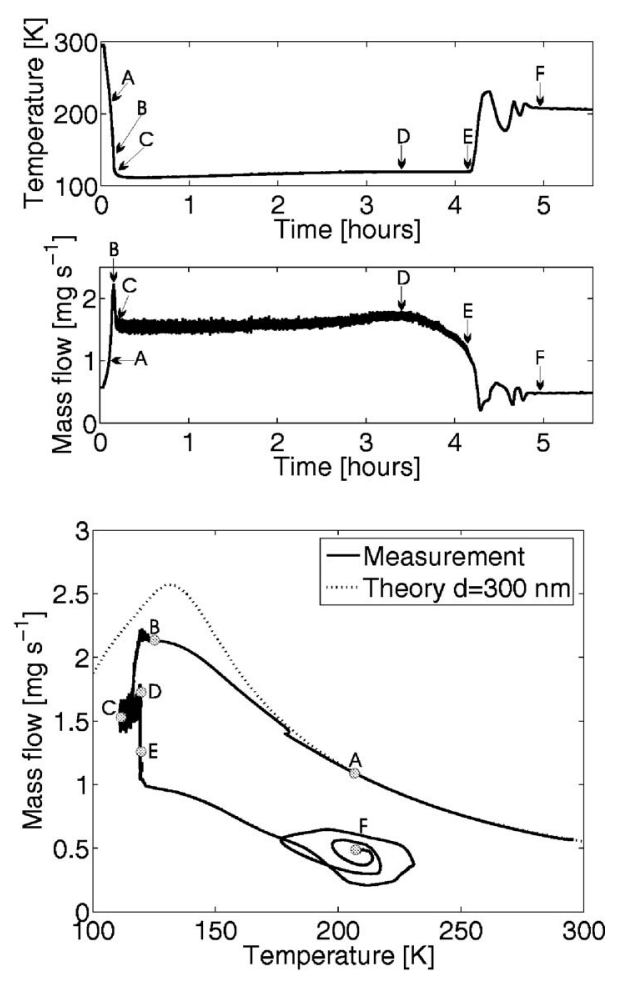
FIG. 2. Cooldown measurement of the cold stage. the evaporator reaches the sublimation temperature and the
Downloaded 02 Nov 2007 to 131.155 .151 .77 . Redistribution subject to AIP license or copyright, see http://apl.aip.org/apl/copyright.jsp nearly zero, see Fig. 1. A large portion of the water, about 99.9\%, deposits in the CFHX area with a temperature between 200 and $160 \mathrm{~K}$ (main deposition area, see Fig. 1). From this point, the water contamination inside the nitrogen gas has decreased by a factor of $10^{3}$ (i.e., from 1 to $10^{-3} \mathrm{~Pa}$ ). From point $\mathrm{C}$ to $\mathrm{D}$ the temperature of the cold tip increases slightly because of condensation of residual air molecules in the vacuum space at the outside of the cooler. The surface of the cold stage is covered with a reflective gold layer of which the emissivity increases. During a long period of time (in this experiment $3 \mathrm{~h}$ from point $\mathrm{C}$ to $\mathrm{D}$ ) nearly all water molecules deposit inside the main deposition area creating a thin layer of ice crystals on the CFHX surface. We assume that as this layer grows thicker, at some point the cohesion between the crystals becomes so weak that they disconnect and diffuse through the CFHX forced by the flow. When they reach the restriction, they get stuck inside and block the flow (point $\mathrm{D}$ to $\mathrm{E})$. The mass flow decreases and as a result the cooling power drops. At a certain point $(t=4.2 \mathrm{~h}$, point $\mathrm{E})$, the cooling power can no longer compensate for parasitic heat losses and the tip temperature increases. Due to this temperature increase, the mass flow decreases further and the cold tip heats up returning to a stable situation $(\mathrm{F})$.

In a similar experiment, a cold stage was used without a gold layer on the outside so that it was possible to look inside the glass cooler during operation. Figure 3 shows four frames of a video that was taken during cooldown, showing the deposited water inside the cooler. In this experiment, as in the previous one, most of the water deposits in the main deposition area of the CFHX for a long period of time. As a result of the clogging of the restriction, the mass flow drops and the cold stage starts to warm up (point 1). In the corresponding frame no solid water can be seen in the filmed area. As the evaporator and the restriction warm up, the temperature gradient over the CFHX decreases and the main deposition area moves toward the cold tip. This is visualized in Fig. 3 by subtracting frame 1 from frame 2. At 2, the temperature of evaporator has increased to such an extent that this transition zone enters the restriction and the evaporator. The evaporator temperature rises further to point 3 . Now a large amount of solid water has moved from the CFHX into the evaporator. The clogging of the restriction has now reached a maximum (flow is minimum). A cloud of deposited water can now be seen in the movie frame. From 4 to 5 , the evaporator reaches the sublimation temperature and the subject to AIP license or copyright, see http://apl.aip.org/apl/copyright.jsp 

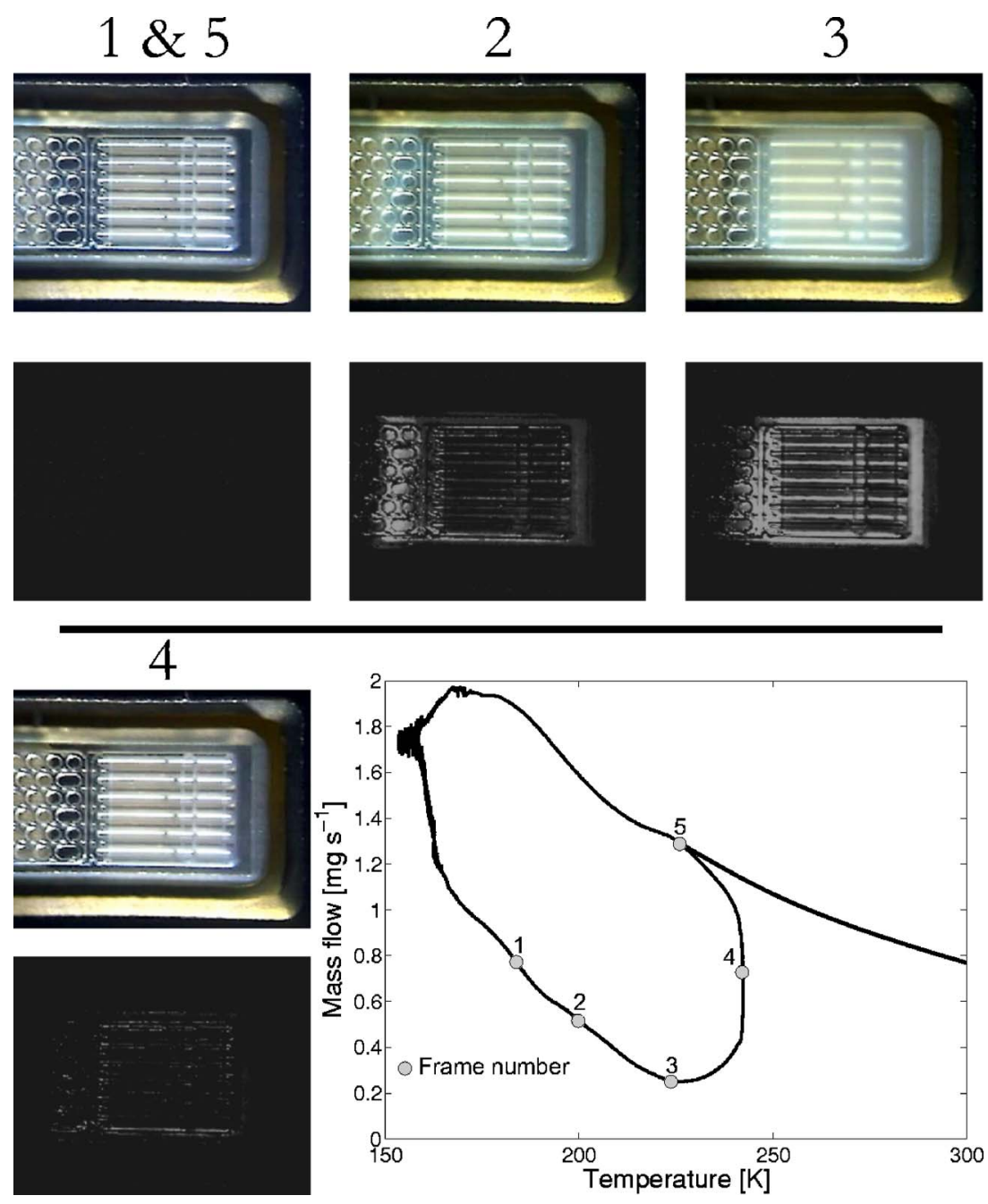

FIG. 3. Six different frames of a movie taken from the tip of the cold stage during operation. Below every frame a subtraction of the current frame and frame 1 is depicted. Bottom right: measurement data.

deposited water transitions back to vapor and is dragged away with the flow. The system now contains no more solid water molecules and the mass flow has returned to its original value so the cold stage can cool down again (point 5, the corresponding frame is the same as for 1). In contrast to the measurement shown in Fig. 2, a stable end situation is not reached. This is because there is no reflective shield on the evaporator, increasing the local parasitic heat loss and therefore the temperature lies above the local sublimation temperature of water.

In summary, the clogging of MEMS based microcoolers was investigated. Water molecules deposit inside the CFHX and deposited ice crystals migrate to the flow restriction, thus blocking the flow and reducing the cooling power. As a result, the cold tip warms up and the water deposition area moves to the evaporator part. A video taken during cooldown shows the deposited water inside the cooler that sublimates back to vapor, thus declogging the system. In the future, these microcoolers will be combined with small compressors, thus establishing closed-cycle microrefrigerators. By carefully pumping and purging these devices prior to closing, the amount of residual water can be limited. The remaining water will be trapped in the CFHX and can be sublimated back to vapor as described above. A small heater at the cold tip can be applied to force this process. We anticipate that in a few steps all water present in the system can be moved through the cold stage and collected at the warm end by adequate filtering. In this respect, the application of sorption compressors is very attractive. ${ }^{11,12}$

This work is supported by the Dutch Technology Foundation (STW) under Project No. TTF.5677.

${ }^{1}$ C. C. Yang, B. L. Nelson, B. R. Allen, W. L. Jones, and J. B. Horton, IEEE Trans. Microwave Theory Tech. 41, 992 (1993).

${ }^{2}$ A. Mahdi and D. Mapps, Sens. Actuators, A 81, 367 (2000).

${ }^{3}$ P. P. P. M. Lerou, G. Venhorst, C. Berends, T. T. Veenstra, M. Blom, J. F. Burger, H. J. M. ter Brake, and H. Rogalla, J. Micromech. Microeng. 16, 1919 (2006).

${ }^{4}$ S. Garvey, S. Logan, R. Rowe, and W. A. Little, Appl. Phys. Lett. 42, 1048 (1983).

${ }^{5}$ S. Jeong, Int. J. Refrig. 27, 309 (2004).

${ }^{6}$ P. P. P. M. Lerou, T. T. Veenstra, J. F. Burger, H. J. M. ter Brake, and H. Rogalla, Cryogenics 45, 659 (2005).

${ }^{7}$ H. Henmi, S. Shoji, Y. Shoji, K. Yoshimi, and M. Esashi, Sens. Actuators, A 43, 243 (1994).

${ }^{8}$ Y.-T. Cheng and W.-T. Hsu, J. Microelectromech. Syst. 11, 556 (2002).

${ }^{9}$ B. Lee, S. Seok, and K. Chun, J. Micromech. Microeng. 13, 663 (2003).

${ }^{10}$ A. Roth, Vacuum Technology, 3rd ed. (Elsevier, Amsterdam, 1990), pp. 123-148.

${ }^{11}$ J. F. Burger, H. J. M. ter Brake, H. Rogalla, and M. Linder, Cryogenics 42, 97 (2002).

${ }^{12}$ G. Wiegerinck, J. Burger, H. Holland, E. Hondebrink, H. J. M. ter Brake, and H. Rogalla, Cryogenics 46, 9 (2006).

${ }^{13}$ Cryodata Inc. (http://www.cryodata.com). 